\title{
Regional Character of the "Global Monsoon" PALEOCLIMATE INSIGHTS FROM NORTHWEST INDIAN LACUSTRINE SEDIMENTS
}

\author{
By Yama Dixit
}

ABSTRACT. The concept of a "global monsoon" proposes that the annual insolation cycle and global-scale atmospheric circulation drive and synchronize regional monsoons. However, model, proxy, and observational studies reveal differences in the regional variability of the summer monsoon and its direct response to solar forcing and glacial boundary conditions. Here, we focus on paleoenvironmental data derived from paleolake sediments in northwest India. These paleolakes straddle a precipitation gradient from sub-humid to semi-arid to arid plains and contain a wealth of information about summer monsoon variability at regional scale over the past 10,000 years. The paleolake records provide compelling evidence of significant regional differences in the timing of monsoon responses to orbital forcings; only sub-humid to semi-arid lakes resemble monsoon reconstructions from marine sediment and speleothem archives, while the arid region lakes contain regional hydroclimate histories. Extracting regional trends from the global signature of monsoon variability is necessary for understanding the regional impact of future climate warming on the monsoon system and human populations. The paleolakes in northwest India highlight the importance of considering the specific location of archive and signal heterogeneity when interpreting monsoon records. Results indicate that detailed records are required from other monsoon regions to improve knowledge of the imprints of the complex monsoon system at regional scales.

\section{INTRODUCTION}

With rising global atmospheric greenhouse gas concentrations due to anthropogenic activities, society is increasingly interested in understanding climate variations and their potential effects-past, present, and future-on human civilizations. One of the most significant impacts of climate change is predicted to be on the global hydrological cycle (IPCC, 2014). The Indian summer monsoon (ISM) plays a critical role in the global hydrological cycle by regulating mass and energy exchanges between the atmosphere over the mid-latitudes and the tropics (Gupta et al., 2003). The Indian subcontinent has long depended upon ISM rainfall for the agricultural activities that are critically important to the Indian economy (Gadgil and Kumar, 2006). India's burgeoning population depends on agriculture both directly, by using agricultural products, and indirectly, by employment, rural livelihoods, and supplies to other economic sectors that use agricultural products (such as textile and food industries). Therefore, variations in the intensity of the ISM are likely to have widespread socioeconomic impacts in the modern Indian subcontinent. Recent monsoonrelated catastrophic events (e.g., Sinha, 2008; Pal and Al-Tabbaa, 2009; Mishra and Nagaraju, 2019) underscore the importance of examining the variabil- ity of the ISM at various timescales and developing reliable predictions in order to mitigate the catastrophic consequences of monsoon rainfall anomalies.

The ISM is a part of the "global monsoon" that constitutes the coherent responses of all monsoon systems to changes in global-scale atmospheric circulation patterns forced primarily by the annual solar cycle and by land-air-sea interactions (B. Wang and Ding, 2008). This unified global monsoon concept suggests that a single tropical and subtropical atmospheric system influences the Indian subcontinent and Central and East Asia in a similar manner (P.X. Wang et al., 2017). Global monsoon dynamics are shaped by large-scale meridional temperature gradients and the position of the Intertropical Convergence Zone (ITCZ), which is seasonally displaced by crossequatorial pressure gradients (Donohoe et al., 2013; Figure 1). A similar mechanism is believed to result in summer rainfall in North Africa and Central and East Asia between June and September. These regional components of the global monsoon system are thought to be closely linked through forcing and feedback processes, suggesting that a change in any component may cause a chain reaction that affects the entire system homogeneously (Kim et al., 2008; P.X. Wang et al., 2017). Consequently, a global perspective is proposed to be more useful for evaluating future variability in monsoon systems (Kim et al., 2008; P.X. Wang et al., 2017). 


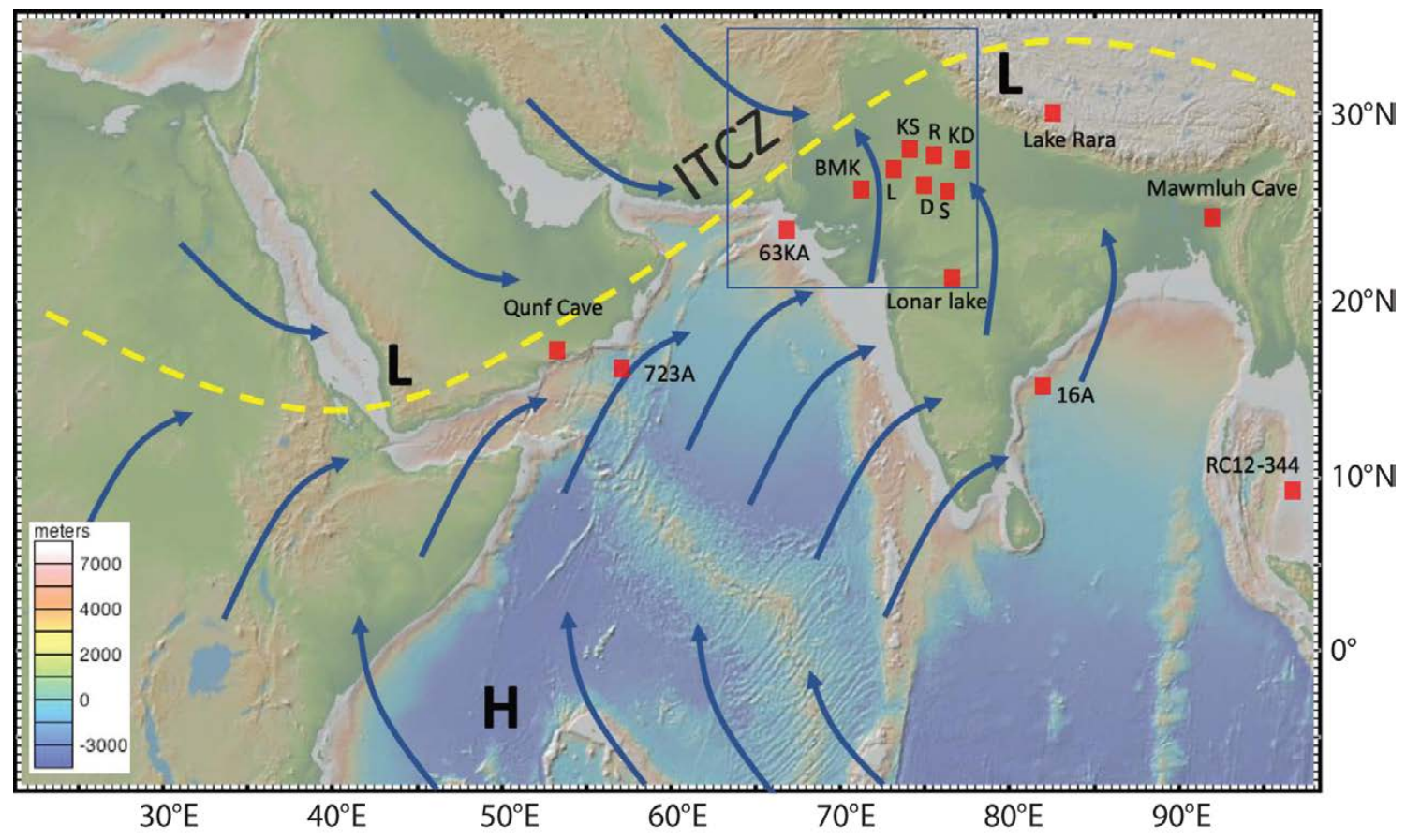

FIGURE 1. Physiographic map of the Indian subcontinent and adjacent ocean regions with a schematic of surface wind patterns. Blue arrows indicate the general directions of the Arabian Sea and Bay of Bengal branches of the Indian summer monsoon. The yellow dashed line denotes the position of the Intertropical Convergence Zone (ITCZ) during Northern Hemisphere summertime, with lower atmospheric pressure on land $(L)$ and higher pressure over the ocean $(\mathrm{H})$. The annual reversal of surface winds caused by the north-south migration of the ITCZ is thought to create a "global monsoon" across the Indian, Asian, tropical African, and Australian landmasses. The map also locates the prominent marine speleothem and lake proxy records discussed in this study. The blue square highlights the northwest Indian lakes. In the sub-humid region, KD = Kotla Dahar (Dixit et al., 2014a). In the semi-arid region, $\mathrm{R}=$ Paleolake Riwasa (Dixit et al., 2014b, 2015) and S = Sambhar Lake (Sinha et al., 2006). In the Thar Desert, KS = Karsandi (Dixit et al., 2018), D = Didwana (Singh et al., 1990), L = Lunkaransar (Enzel et al., 1999), and BMK = Bap Malar and Kanod playa (Deotare et al., 2004).

In the last several decades, studies of the longer-term variability in the ISM using natural climate archives, including lake and ocean sediments and speleothems (e.g., Y.J. Wang et al., 2001; Fleitmann et al., 2003; Gupta et al., 2003; Staubwasser et al., 2003; Berkelhammer et al., 2012; Dixit et al., 2014b; Cai et al., 2015; Kathayat et al., 2016, and references therein), together with simulations of past monsoon variability, have revealed that the global monsoon system has a substantial regional character and cannot solely be characterized by the common, global dynamics of monsoon systems at different timescales. Instrumental and paleoclimate data have shown that the interplay of various regional forcings cause the monsoon variability observed at different timescales. Therefore, the concept of a global monsoon has been a topic of recent debate, with an increasing number of regional paleoclimate records revealing a divergent monsoon history (Caley et al., 2011; Seneviratne and Hauser, 2020). Thus, there is a great need for more studies aimed at investigating regional monsoon variability and the mechanisms that force regional response patterns.

Despite dedicated efforts, a comprehensive picture of monsoon variability has proved elusive, largely due to the absence of long-term, high-resolution regional paleoenvironmental records, the spatial heterogeneity of monsoon precipitation, and the monsoon's complex forcing mechanisms. Larger regional differences are anticipated in the coming decades, with some regions receiving more rain, despite a projected weakening of monsoon rainfall (IPCC, 2013) and vice versa. ISM rainfall projection remains a key challenge for regional circulation models (Asharaf and Ahrens, 2015). Modern instrumental records (collected since 1871, when the first regional meteorological station was established) are too short to document the full range of past ISM variability and spatial heterogeneity. Therefore, regional paleoclimate studies of monsoon evolution are essential for improved understanding of how natural and anthropogenic forcing impact the monsoon at local scales.

This paper highlights the regional versus the global signal of monsoon dynamics during the Holocene (the last 10,000 years) using inferences derived from lacustrine sedimentary sequences collected from the northwest Indian plains. Composite data from these lake records fill a knowledge gap and resolve a long-standing debate about whether these lakes record local or global signals of monsoon variability. Because northwest India was one of the most variable regions in terms of environmental conditions and cultural evolution during the Holocene, monsoon variability during this period 


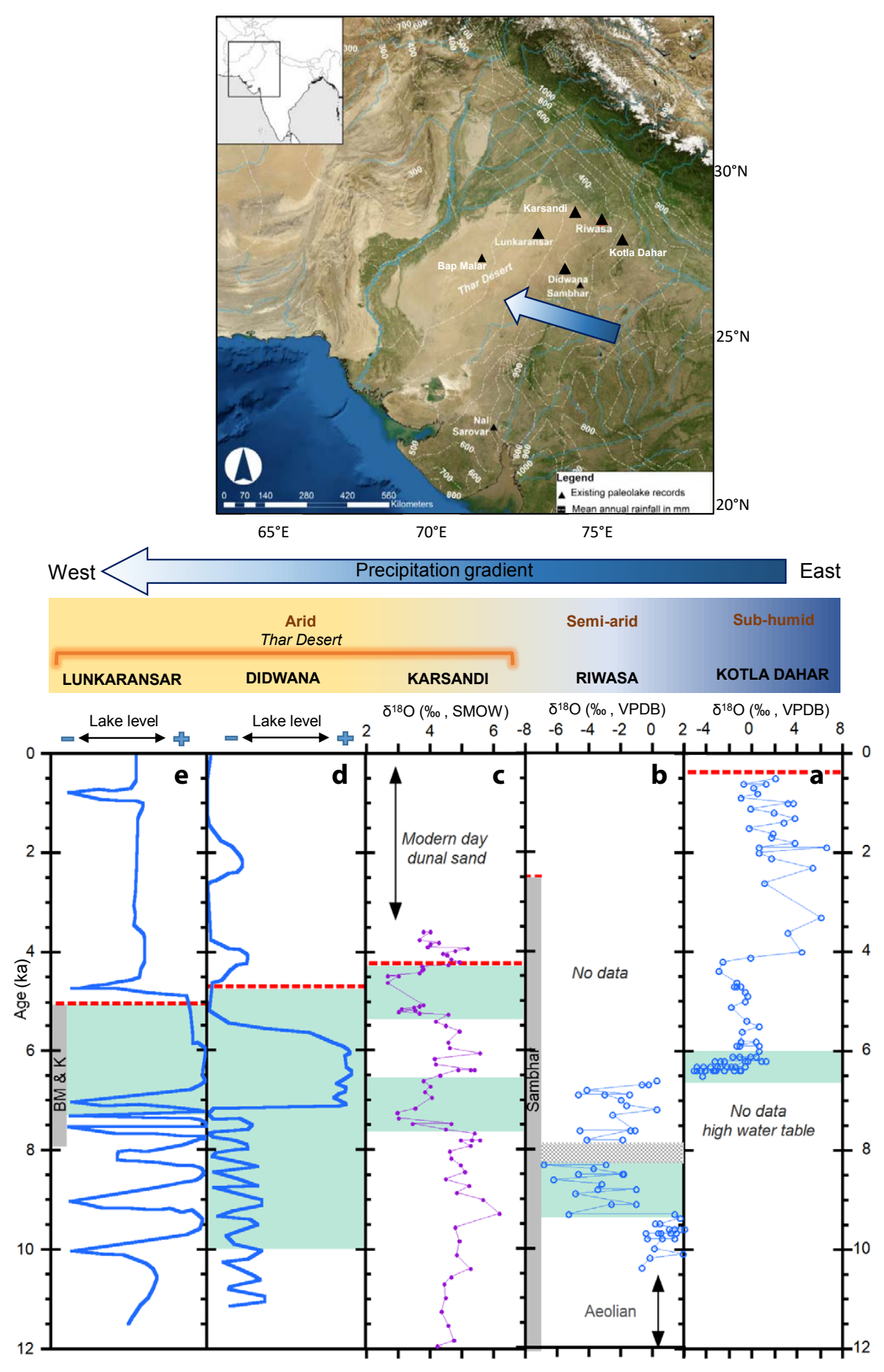

FIGURE 2. Holocene climate reconstructions from lakes in northwest India. Lakes with reasonably robust chronology (that is, each major lithological, sedimentological, and geochemical transition has been age-constrained) were used to infer regional climate history. The lakes and proxies used from east to west (right to left) are: (a) Sub-humid region: Kotla Dahar, with $\delta^{18} \mathrm{O}_{\text {gastropod }}$ reflecting regional evaporation/precipitation (E/P) changes (Dixit et al., 2014a). (b) Semi-arid region: Riwasa, with $\delta^{18} \mathrm{O}_{\text {gastropod }}$ reflecting regional E/P changes (Dixit et al., 2014b). (c) Arid region (Thar Desert): Paleolake Karsandi, with $\delta^{18} \mathrm{O}$ of gypsum hydration water reflecting lake water $\delta^{18} \mathrm{O}$ and regional E/P changes (Dixit et al., 2018). Lake levels are from Prasad and Enzel (2006). (d) Didwana (Singh et al., 1990). (e) Lunkaransar (Enzel et al., 1999). Vertical gray bars in (b) and (e) denote periods with permanent lake levels where age definition is poor: Sambhar Lake (Sinha et al., 2006) and Bap Malar and Kanod playa (BM\&K) (Deotare et al., 2004). Green shaded bars denote the wettest periods during the Holocene inferred from geochemical proxies, although these wet periods were interrupted by intervals of aridity. Red dashed lines mark the disappearances of permanent lakes-the sequence of drying follows the east-west path of the Bay of Bengal branch of the modern monsoon: the lakes that lie farthest west dried first, and the easternmost dried last. has been linked to the evolution of the ancient Bronze Age Indus Civilization (Dixit et al., 2014a; Petrie et al., 2017). The objective here is to critically examine the fidelity of regional terrestrial paleoenvironmental archives as recorders of ISM variability and to compare them with prominent monsoon records from marine and terrestrial archives.

The northwest Indian plains receive over $80 \%$ of their rainfall from the Bay of Bengal arm of the strong southwesterly summer monsoon between June and September (Bhattacharya et al., 2003; Sengupta and Sarkar, 2006). The resulting east-west precipitation gradient (Figure 2) lends a distinct character to the region, such that the sedimentology and geochemistry of paleolake archives change every few hundred kilometers. We focus on an east-to-west transect of lake sediment records that record a progressive decrease in monsoon precipitation: Kotla Dahar in the sub-humid region (Dixit et al., 2014a); Riwasa and Sambhar Lake in the semi-arid region (Dixit et al., 2014b, and Sinha et al., 2006, respectively); and in the western arid region, within the Indian state of Rajasthan, the Thar Desert lakes, including Karsandi (Dixit et al., 2018), Didwana (Singh et al., 1990), Lunkaransar (Enzel et al., 1999), and Bap Malar and Kanod playa (Deotare et al., 2004). We appreciate and emphasize that further high-resolution regional terrestrial records are required to develop a complete understanding of monsoon imprints at regional scale.

\section{GLOBAL VERSUS REGIONAL MONSOON VARIABILITY DURING THE HOLOCENE}

Because northwest India receives most of its annual rainfall during the summer months via the ISM, regional lake archives should provide relatively independent summer monsoon histories that are similar to those of the global monsoon. When examining lacustrine records, robust chronological control is critical to avoid the possibility of confusing regional vs global monsoon differences. In general, 
proxy reconstructions with at least one radiocarbon $\left({ }^{14} \mathrm{C}\right)$ age associated with every distinct geochemical and lithological change permits adequate dating. Using this criterion, five well-dated lake records were selected, three from the westernmost Thar Desert region and one each from the semi-arid and sub-humid regions (Figure 2 and Table 1).

Although abundant gastropod and ostracod carbonate shells generally characterize lacustrine sediments, lakes in arid environments often lack well-preserved carbonate tests for ${ }^{14} \mathrm{C}$ dating and isotopic analyses. This is true for most of the Thar Desert lake records. However, lakes in the east (Riwasa and Kotla Dahar) provide robust chronology based on ${ }^{14} \mathrm{C}$ dating of abundant gastropod shells preserved in the lake sediments. In addition, a recent study shows that water isotopes of evaporative salts, such as gypsum, which are often plentiful in arid environment lacustrine sediments, can be used as a novel proxy for lake water conditions (Hodell et al., 2012).

Pioneering work on regional hydroclimate reconstructions for the northwest Indian lakes was carried out using pollen assemblages to determine the relative abundance of $\mathrm{C}_{3}$ plants (suggesting higher rainfall) versus $\mathrm{C}_{4}$ plants (suggesting lower rainfall; Singh et al., 1972). The desert lakes were later revisited, and improved hydroclimate records with robust chronologies were obtained using sedimentological and mineralogical analyses of Lake Didwana sediments (Wasson et al., 1984) and sedimentological and organic matter $\delta^{13} \mathrm{C}$ analyses of Lake Lunkaransar sediments (Enzel et al., 1999). In general, these lakes were formed in several basins as a result of relatively wet conditions that occurred during the early to mid Holocene (Saini et al., 2005; Prasad and Enzel, 2006; Dixit et al., 2018). Paleolakes Lunkaransar, Didwana, and Karsandi in the arid region, and Riwasa and Sambhar in the semi-arid region, all appeared when the monsoon intensified following the precessionally controlled boreal summer insolation (Figure 2). This coherent response of northwest Indian lakes to an intensified summer monsoon after the last glacial period was followed by diverging intensities in monsoon history; the early Holocene ISM maxima, observed as very low $\delta^{18} \mathrm{O}$ values in gastropod shells in paleolakes Kotla Dahar and Riwasa in the east, does not coincide with maximum lake levels in Thar Desert lake records. A very high evaporation/precipitation $(\mathrm{E} / \mathrm{P})$ ratio in the Thar Desert and the lack of a large drainage basin generally led to lower lake levels and formation of ephemeral lakes at Lunkaransar and Didwana during the early Holocene (Prasad and Enzel, 2006). In contrast, eastern lakes were either located in regions with lower E/P or were part of a large lake system whose maximum lake levels occurred during the early Holocene monsoon intensification. The mid-Holocene ( 7.0-5.0 ka) was wetter than the early Holocene in the Thar Desert lakes region (Figure 2c-e), because of relatively lower $\mathrm{E} / \mathrm{P}$ in response to decreasing summer insolation, which in turn led to a net increase in effective moisture (i.e., P-E; Wasson et al., 1984; Prasad and Enzel, 2006; Dixit et al., 2018). An additional source of moisture from the northeast during wintertime is also suggested, and this would have helped to maintain high Thar Desert lake levels during the mid-Holocene (Enzel et al., 1999). The eastern lakes (Kotla Dahar and Riwasa), on the other hand, responded to the progressive decline in general monsoon rainfall following the decreasing summer insolation during the mid-Holocene (Dixit et al., 2014a,b).

Apart from the diachronous response of northwest Indian lakes to general monsoon variability, there are also distinct differences in the way these lake

TABLE 1. Details of records derived from northwest Indian lakes in east-west order. Note that the chronologies of Lakes Sambhar and Bap Malar are poorly defined during the Holocene.

\begin{tabular}{|c|c|c|c|c|c|c|c|}
\hline $\begin{array}{l}\text { LACUSTRINE } \\
\text { ARCHIVES }\end{array}$ & BAP MALAR & LUNKARANSAR & DIDWANA & KARSANDI & SAMBHAR & RIWASA & KOTLA DAHAR \\
\hline References & $\begin{array}{c}\text { Deotare et al., } \\
2004\end{array}$ & $\begin{array}{l}\text { Singh et al., } \\
\text { 1990; Enzel } \\
\text { et al., } 1999\end{array}$ & $\begin{array}{c}\text { Singh et al., } \\
\text { 1990; } \\
\text { Wasson et al., } \\
1984\end{array}$ & Dixit et al., 2018 & $\begin{array}{l}\text { Sinha et al., } \\
2006\end{array}$ & $\begin{array}{l}\text { Dixit et al., } \\
\text { 2014b }\end{array}$ & $\begin{array}{l}\text { Dixit et al., } \\
2014 a\end{array}$ \\
\hline Proxy Used & $\begin{array}{l}\text { Palynology and } \\
\text { mineralogy }\end{array}$ & $\begin{array}{c}\text { Sediment } \\
\text { geochemistry } \\
\left(\delta^{13} \mathrm{C}\right) \text { and } \\
\text { palynology }\end{array}$ & $\begin{array}{l}\text { Sedimentology, } \\
\text { mineralogy, and } \\
\text { palynology }\end{array}$ & $\begin{array}{l}\delta^{18} \mathrm{O} \text { of gypsum } \\
\text { hydration water }\end{array}$ & $\begin{array}{c}\text { Sediment } \\
\text { geochemistry, } \\
\text { mineralogy, } \\
\delta^{18} \mathrm{O} \text { of bulk } \\
\text { carbonate }\end{array}$ & $\begin{array}{l}\delta^{18} \mathrm{O} \text { of } \\
\text { gastropod } \\
\text { shells }\end{array}$ & $\begin{array}{l}\delta^{18} \mathrm{O} \text { of } \\
\text { gastropod } \\
\text { shells }\end{array}$ \\
\hline $\begin{array}{l}\text { Proxy } \\
\text { Indicates }\end{array}$ & $\begin{array}{l}\text { Vegetation } \\
\text { changes }\end{array}$ & $\begin{array}{c}\text { Vegetation } \\
\text { changes and } \\
\text { rainfall variability }\end{array}$ & $\begin{array}{l}\text { Vegetation } \\
\text { changes } \\
\text { and rainfall } \\
\text { variability }\end{array}$ & $\begin{array}{l}\text { Lake water } \\
\delta^{18} \mathrm{O} \text { and } \\
\text { temperature; } \\
\text { (E/P changes) }\end{array}$ & $\begin{array}{c}\text { Rainfall } \\
\text { variability }\end{array}$ & $\begin{array}{l}\text { Lake water } \\
\delta^{18} \mathrm{O} \text { and } \\
\text { temperature; } \\
\text { (E/P changes) }\end{array}$ & $\begin{array}{l}\text { Lake water } \\
\delta^{18} \mathrm{O} \text { and } \\
\text { temperature; } \\
\text { (E/P changes) }\end{array}$ \\
\hline
\end{tabular}

$\mathrm{OSL}=$ Optically stimulated luminescence dating; $\mathrm{E} / \mathrm{P}=$ Evaporation/precipitation 
records exhibit the manifestations of the most prominent abrupt monsoon weakening events of $8.2 \mathrm{ka}$ and $4.2 \mathrm{ka}$ (Dixit et al., 2014a,b). Paleolake Riwasa dried abruptly when lake levels declined and marl sediments were aerially exposed to form hardground at $\sim 8.2 \mathrm{ka}$ (Figure 2b; Dixit et al., 2014b). Interestingly, none of the other northwest Indian lake records provide any signs of drying during this period. There is no evidence of complete desiccation throughout the history of Sambhar playa (Sinha et al., 2006), and the Thar Desert lakes-Bap Malar, Kanod playa, Lunkaransar, Didwana, and Karsandi-were ephemeral fluctuating lakes during this period (Figure 2), devoid of massive biogenic carbonates and underlying deep lake marl sediments (a prerequisite for forming hardground). In contrast, Lake Riwasa was in its freshest and deepest phase before the ISM weakened abruptly after $\sim 8.3 \mathrm{ka}$, causing repeated inundation and aerial exposure of the lake bottom sediments, which formed hardground (Dixit et al., 2014b). Similarly, at Kotla Dahar, a $\sim 4 \%$ increase in $\delta^{18} \mathrm{O}_{\text {gastropod }}$ occurred at $\sim 4.1 \mathrm{ka}$, marking an $\mathrm{E} / \mathrm{P}$ peak in the lake catchment related to the global $4.2 \mathrm{ka}$ abrupt monsoon weakening (Dixit et al., 2014a) that is absent in all the other northwest Indian lake records (Figure 2a). The $\delta^{18} \mathrm{O}$ of gypsum hydration water also indicates drying of Lake Karsandi sometime between $4.4 \mathrm{ka}$ and $3.2 \mathrm{ka}$ (Dixit et al., 2018). However, there is no evidence of abrupt drying, indicating that the lake had already dried out by $4.4 \mathrm{ka}$ due to decreasing summer rainfall (Giesche et al., 2019). Overall, while the drying and permanent decline of lake levels in northwest India mirrors the east-west modern precipitation gradient (Figure 2), significant Holocene monsoon variability is recorded in these lakes, suggesting nonlinear response to monsoon variability and highlighting the importance of local processes and regional monsoon variations. Thus, regional preservation of a global monsoon signal should be treated carefully.

\section{HOLOCENE MONSOON HISTORY FROM TERRESTRIAL AND MARINE ARCHIVES}

A comparative assessment of monsoon variability recorded in northwest Indian lakes clearly indicates that the Thar Desert lakes represent more local climate history than global monsoon variability; semi-arid paleolake Riwasa and subhumid paleolake Kotla Dahar together provide a coherent picture of ISM variability in northwest India. Because none of the northwest Indian lake records offer a continuous Holocene monsoon history, we use records from Riwasa and Kotla Dahar lakes, which have complementary $\delta^{18} \mathrm{O}$ records obtained from the shell carbonates of the gastropod Melanoides tuberculata. Together, the Riwasa-Kotla Dahar composite record and the marine and speleothem monsoon records provide a holistic picture of Holocene ISM variability. The intensified monsoon that followed increased boreal summer insolation after the last glacial period is clearly documented in northwest Indian lake records (Figure 3a) as well as in records from the Arabian Sea and the Bay of Bengal branch of the ISM system. For example, early Holocene monsoon intensification (Figure 3) is supported by speleothems from Bitto Cave (North India; Kathayat et al., 2016), Dongge Cave (China; Y.J. Wang et al., 2005; Figure 3b), and Qunf Cave (Oman; Fleitmann et al., 2003; Figure 3c) and by planktonic foraminifera $\delta^{18} \mathrm{O}$ records from Arabian Sea marine sediment core 63KA (Staubwasser et al., 2003; Figure 3d) and Ocean Drilling Program (ODP) Hole 723A (Gupta et al., 2003; Figure 3e). Evidence for increased summer monsoon precipitation in the Bay of Bengal during the early Holocene is found in sediments from Lonar Lake in central India (Prasad et al., 2014) and in marine sediments (Govil and Naidu, 2011; Rashid et al., 2011; Ponton et al., 2012; Figure 3f,g).

Geochemical records from marine sediments and speleothems reveal gradually decreasing ISM strength in the Holocene following Northern Hemisphere sum- mer insolation (Figure 3a), in line with the Riwasa-Kotla Dahar composite record (Figure 3). This gradually declining monsoon intensity was punctuated by millennial-scale abrupt changes in the composite Riwasa-Kotla Dahar records at $\sim 4.0-4.2 \mathrm{ka}, 5.9-6.0 \mathrm{ka}$, $8.2 \mathrm{ka}, 9.4 \mathrm{ka}, 10.4 \mathrm{ka}$, and $11 \mathrm{ka}$ that are also documented in independently dated speleothem records from southern China (Y.J. Wang et al., 2005) and Oman (Fleitmann et al., 2003), and also in marine records from the Arabian Sea (Gupta et al., 2003; Figure 3). The coincident timing of abrupt monsoon variability and North Atlantic cold events (i.e., Bond events) against a backdrop of gradual insolation forcing through the Holocene suggests an atmospheric teleconnection (Gupta et al., 2003). The most prominent cooling event at $8.2 \mathrm{ka}$ in the North Atlantic during the Holocene is consistent with an abrupt monsoon weakening episode recorded in Lake Riwasa and in a stalagmite from southern Oman (Fleitmann et al., 2003; Gupta et al., 2003), in speleothems in China (Y.J. Wang et al., 2005; Cheng et al., 2009) and on the Tibetan Plateau (Cai et al., 2015), and in Arabian Sea sediments (Gupta et al., 2003; Staubwasser et al., 2003; Figure 3).

The 4.2 ka climate event in lake Kotla Dahar (Dixit et al., 2014a) has also been observed in several other terrestrial records on the Indian subcontinent, including the Mawmluh Cave speleothems (Meghalaya) in northeastern India (Berkelhammer et al., 2012; Kathayat et al., 2018). In fact, the most recent of the three subdivisions of the Holocene epoch (beginning at $\sim 4.2 \mathrm{ka}$ ) is named Meghalayan Age, a reference to the northeastern Indian state of Meghalaya, where Mawmluh Cave is located (Walker et al., 2019). A less abrupt, yet still arid, period that highlights significant regional variability is also documented in a peat profile from north central India (Phadtare, 2000), at Lonar Lake ( 4.6-3.9 ka; Menzel et al., 2013), and in western Nepal at Rara Lake ( 4.2-3.7 ka; Nakamura et al., 
2016). Recently, $\delta^{18} \mathrm{O}$ measured on a variety of foraminifera species from a sediment core collected off Pakistan revealed a reduction in both summer and winter monsoon rainfall at $\sim 4.1 \mathrm{ka}$ over the general northwest Indian subcontinent (Giesche et al., 2019).

Current understanding of the forcing responsible for the $4.2 \mathrm{ka}$ event highlights a prominent role of tropical Pacific Ocean dynamics, such as El Niño-Southern Oscillation (ENSO) and the Indian Ocean Dipole (IOD; Berkelhammer et al., 2012). The timing of ISM weakening at 4.2 ka coincides, within chronological error, with proxy records from the Pacific Ocean, suggesting increased frequency and intensity of ENSO events (Toth et al., 2012), modulated by the IOD. Increased ENSO activity and the negative phase of the IOD act to suppress summer monsoon circulation via increased subsidence of the Indian subcontinent (Ashok et al., 2004; Berkelhammer et al., 2012; Ishizaki et al., 2012; C. Wang, 2019).

\section{CLIMATE-CULTURAL EVOLUTION IN NORTHWEST INDIA}

During the middle Holocene $(\sim 5.2-2.3 \mathrm{ka})$, northwest India was occupied by the largest Bronze Age civilization, the Indus Civilization (Wright, 2010; Figure 4). There has been a longstanding debate on what led to the collapse of the urban phase of the Indus Civilization. Primarily based on agriculture, its cultural evolution was likely linked with monsoon variability, with the transformation from early ( 5.2-4.5 ka) to urban (4.5-3.9 ka) phase coinciding with a period of high summer and winter rainfall in the region (Dixit et al., 2018; Giesche et al., 2019). Similar to its trading partners in Mesopotamia and Egypt, the collapse of the urban phase of the Indus civilization was likely triggered by an abrupt drying event at $\sim 4.2 \mathrm{ka}$ (Possehl, 2003; Staubwasser et al., 2003; Dixit et al., 2014a; Weiss, 2016). A rapid increase in $\delta^{18} \mathrm{O}$ values of gastropod shell carbonate in Lake Kotla Dahar sediments indicates an abrupt monsoon weakening, and corroborates marine sediment and speleothem studies (Gupta et al., 2003; Staubwasser et al., 2003; Berkelhammer et al., 2012; Giosan et al., 2012; Ponton et al., 2012; Kathayat et al., 2016, 2018; Figure 3). Recent paleoclimate data suggests that Indus urbanism was flourishing around $4.2 \mathrm{ka}$, but

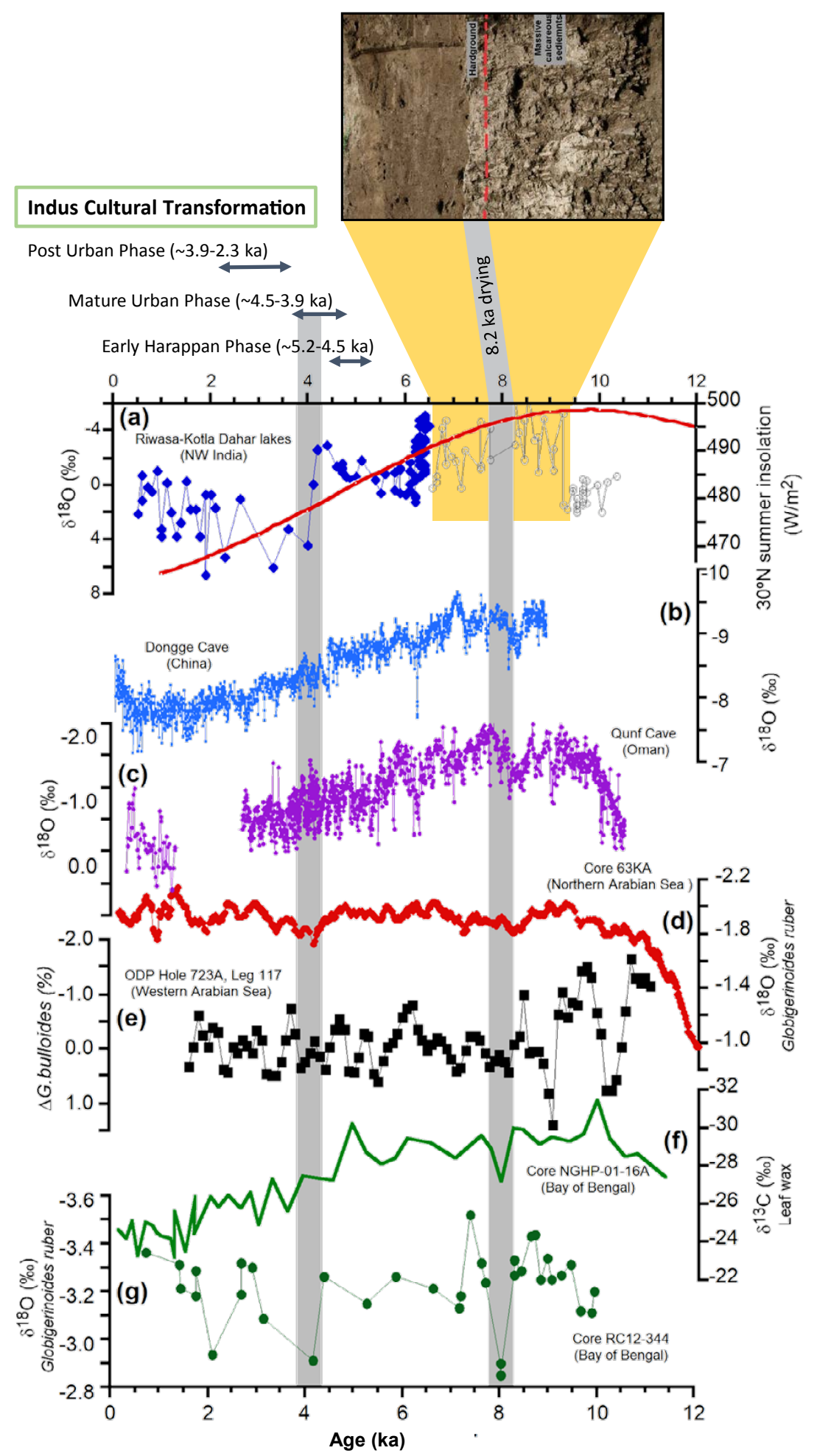

FIGURE 3. Comparison of Holocene summer monsoon history recorded in northwest Indian lakes with prominent distant marine and speleothem records. (a) $\delta^{18} \mathrm{O}_{\text {gastropod }}$ from Riwasa and Kotla Dahar lakes combined reflecting E/P changes in the region and summer insolation at $30^{\circ} \mathrm{N}$ in red (Berger, 1978). (b) and (c) Speleothem records from Dongge cave (China; Y.J. Wang et al., 2005) and Qunf cave (Oman; Fleitmann et al., 2003) with $\delta^{18} \mathrm{O}$ indicating rainfall changes. (d) and (e) Marine records influenced by the Arabian Sea branch of the ISM: (d) foraminifera $\delta^{18} \mathrm{O}$ from the northern Arabian Sea indicating rainfall changes (Staubwasser et al., 2003). (e) G. bulloides abundance (\%) indicating upwelling caused by monsoon surface winds (Gupta et al., 2003).) (f) and (g) Marine records influenced by the Bay of Bengal branch of the ISM: (f) $\delta^{13} \mathrm{C}$ of leaf wax indicating relative abundance of $\mathrm{C}_{3}$ (high rainfall) compared to $\mathrm{C}_{4}$ (lower rainfall) plants (Ponton et al., 2012). (g) Foraminifera $\delta^{18} \mathrm{O}$ indicating rainfall changes (Rashid et al., 2011). Gray bars denote abrupt drying at $\sim 8.2$ ka (observed as desiccation and formation of a hardground, seen at the top) and at $\sim 4.2$ ka (coinciding with the end of the mature urban phase of the Indus Civilization). Indus cultural transformations during mid to late Holocene are also shown at top. 
that de-urbanization soon followed, with new settlements preferentially located in eastern regions (Giosan et al., 2012; Petrie et al., 2017; Dixit et al., 2018; Figure 4). The hydroclimatic stress following the 4.2 ka drying probably led to a decrease in agricultural surpluses that supported the Indus populations, which in turn contributed to diminished social complexity and gradual abandonment of Indus cities (Weber, 2003; Madella and Fuller, 2006; Petrie and Bates, 2017; Pokharia et al., 2017). Archaeobotanical analyses revealed the $4.2 \mathrm{ka}$ drought caused a shift in subsistence practices towards more drought-tolerant, rain-fed crops and increased reliance on two cropping seasons, Rabi (winter)-Kharif (summer) (Madella and Fuller et al., 2006; Petrie and Bates, 2017). An eastward migration of populations following the $4.2 \mathrm{ka}$ drought and a drastic increase in settlements in the eastern regions, which experienced more reliable and direct summer monsoon rains, is suggested to have ultimately contributed to reduced populations and collapse of the urban Indus region (Figure 4; Giosan et al., 2012; Petrie et al., 2017; Dixit et al., 2018). Although the hydroclimatic stress associated with the $4.2 \mathrm{ka}$ event would have been instrumental in shaping Indus cul-

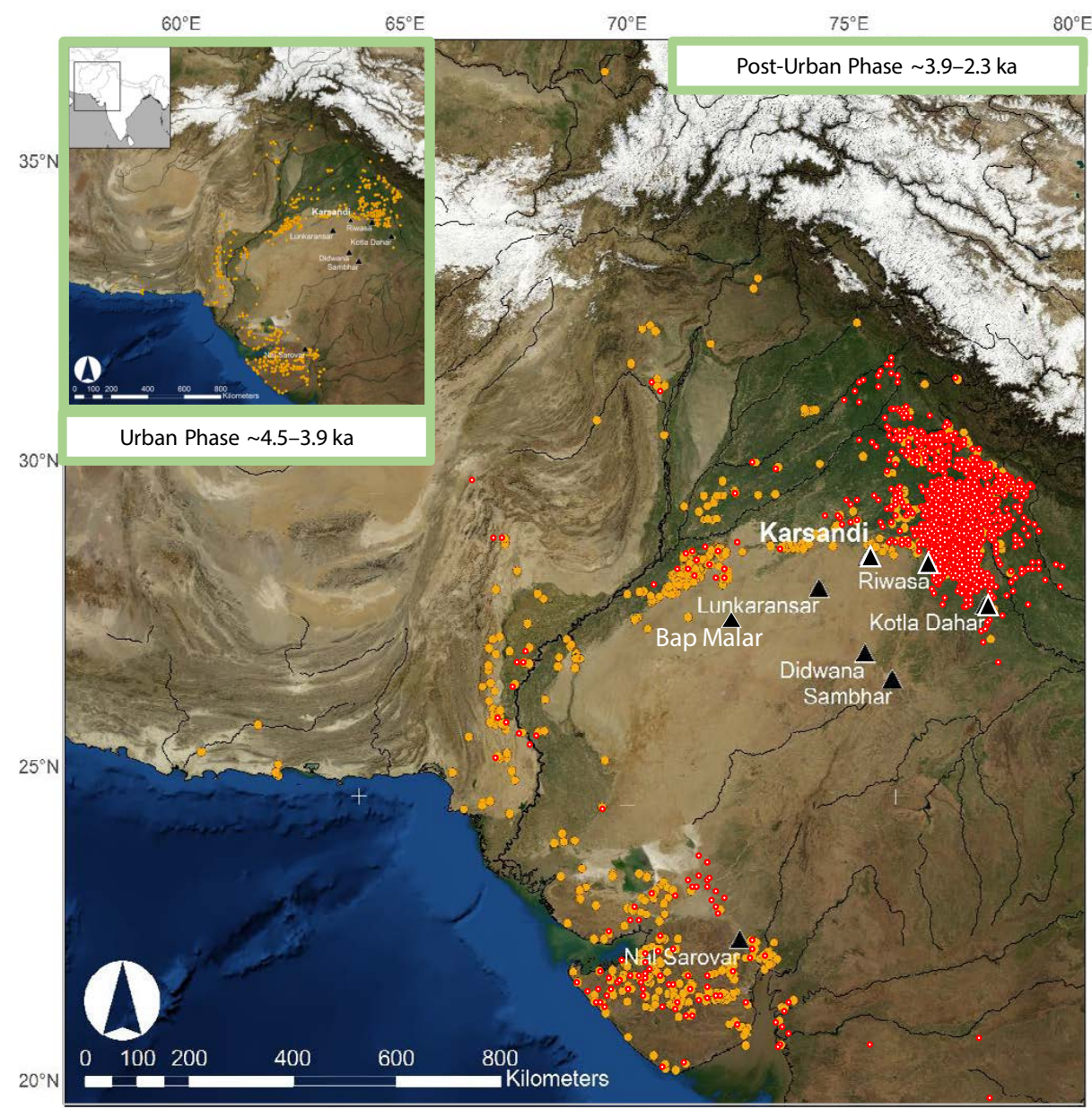

FIGURE 4. Map showing northwest Indian locations of lake records (black triangles) and archaeological sites described in the text along with Indus Civilization population concentrations. Red dots denote the post-urban phase of the Indus Civilization from 3.9 ka to $2.3 \mathrm{ka}$. The inset map shows urban phase locations (orange dots) from 4.5 ka to 3.9 ka (Petrie et al., 2017). Notably, a clear concentration of post-urban settlements (mostly village-based) in the east after the $\sim 4.2$ ka drying event indicates eastward migration of Indus populations toward more reliable rain-fed regions. The far upper left inset map locates the main map in relation to the Indian subcontinent. Paleolakes Kotla Dahar and Riwasa lie in close proximity to several Indus sites and are well suited for reconstructing regional hydroclimate history in order to examine the climate-cultural relationship in the region. tural transformation, it seems inappropriate to simply attribute the collapse of an entire civilization directly to a single climatic event. As the Indus civilization spanned a wide range of ecological and environmentally diverse regions, more regional studies documenting the local climate history are required to understand the complex human-climate correlation in the Bronze Age era.

\section{RATIONALE FOR EXAMINING REGIONAL VS GLOBAL MONSOON VARIABILITY}

The lacustrine records presented here illustrate the variable nature of monsoon signals recorded across northwest India. However, the northwest Indian lake records do not fully document the hydroclimate of the entire Indian subcontinent because of the heterogeneity of monsoon expressions at regional and local scales. Considering the fact that terrestrial records exhibit local climatic conditions more effectively than marine sediment records, it is remarkable that records from the eastern lakes (Riwasa-Kotla Dahar) and marine sediments collectively reflect the global monsoon signal. Both indicate gradual monsoon weakening following boreal summer insolation during the Holocene and abrupt drying at $\sim 8.2$ and $4.2 \mathrm{ka}$. While the work described here focuses on Holocene monsoon variability, marine sediments recovered from International Ocean Discovery Program (IODP) Expedition 353 in the Bay of Bengal will enable further exploration of the coupling of basin-scale monsoon winds and continental precipitation (Clemens et al., 2015).

The divergent climate history of the Thar Desert and the eastern plains of northwest India demonstrate that regional monsoon responses differ in terms of sensitivity and timing. Indeed, the Thar Desert paleoclimate records may help to elucidate the regional characteristics of the monsoon and to better understand the internal feedbacks within the global climate system. Our records demonstrate that it is not appropriate to examine the 
impacts of past and future climate change on societal changes in the entire region based on an oversimplified global monsoon signal or only from a single regional climate record. In order to understand intricacies within ancient civilizations (e.g., the Bronze Age Indus civilization), it is important to develop a network of well-dated paleoenvironmental records that spans the entire region occupied by that civilization. Regional paleoclimate records are equally important for assessing the ability of climate models to simulate monsoon changes at regional scales and for testing model-derived hypotheses. For example, to translate regional observations into larger, global monsoon dynamics, an integrative approach that superimposes regional energy and moisture conservation on global monsoon dynamics is needed. A recent modeling study designed to examine climate extremes using Coupled Model Inter-comparison Projects (CMIP5 and CMIP6) highlights the need to consider regional climate sensitivity as a distinct feature of Earth system models and a key determinant of regional impacts (Seneviratne and Hauser, 2020). Our data suggest that researchers undertake a coordinated effort to integrate terrestrial and marine paleoclimate and paleoenvironmental records with multi-scale model-based quantifications in order to accurately project future climate changes. Such an approach will aid researchers in identifying the causes of observed mismatches between theory, models, and observations of monsoon dynamics, and ultimately in improving the accuracy of regional climate projections. @

\section{REFERENCES}

Asharaf, S., and B. Ahrens. 2015. Indian summer monsoon rainfall processes in climate change scenarios. Journal of Climate 28(13):5,414-5,429, https://doi.org/10.1175/JCLI-D-14-00233.1.

Ashok, K., Z. Guan, N.H. Saji, and T. Yamagata. 2004 Individual and combined influences of ENSO and the Indian Ocean dipole on the Indian summer monsoon. Journal of Climate 17(16):3,141-3,155, https://doi.org/10.1175/1520-0442(2004)017<3141: IACIOE>2.0.CO;2.

Berger, A. 1978. Long-term variations of daily insolation and quaternary climatic changes. Journal of the Atmospheric Sciences 35(12):2,362-2,367, https://doi.org/10.1175/1520-0469(1978)035<2362: LTVODI>2.0.CO;2.
Berkelhammer, M., A. Sinha, L. Stott, H. Cheng, F.F.S.R. Pausata, and K. Yoshimura. 2012. An abrupt shift in the Indian monsoon 4000 years ago. Pp. 75-87 in Climates, Landscapes, and Civilizations. L. Giosan, D.Q. Fuller, K. Nicoll, R.K. Fland, and P.D. Clift, eds, American Geophysical Union, Geophysical Monograph Series, vol. 198, Washington, DC, https://doi.org/ 10.1029/2012GM001207.

Bhattacharya, S.K., K. Froehlich, P.K. Aggarwal, and K.M. Kulkarni. 2003. Isotopic variation in Indian Monsoon precipitation: Records from Bombay and New Delhi. Geophysical Research Letters 30(24), https://doi.org/10.1029/2003GL018453.

Cai, Y., I.Y. Fung, R.L. Edwards, Z. An, H. Cheng, J.-E. Lee, L. Tan, C.-C. Shen, X. Wang, J.A. Day, and others. 2015. Variability of stalagmiteinferred Indian monsoon precipitation over the past 252,000 y. Proceedings of the National Academy of Sciences of the United States of America 112(10):2,954-2,959, https://doi.org/ 10.1073/pnas.1424035112.

Caley, T., B. Malaizé, M. Revel, E. Ducassou, K. Wainer, M. Ibrahim, D. Shoeaib, S. Migeon, and V. Marieu. 2011. Orbital timing of the Indian, East Asian and African boreal monsoons and the concept of a 'global monsoon.' Quaternary Science Reviews 30(25-26):3,705-3,715, https://doi.org/ 10.1016/j.quascirev.2011.09.015.

Cheng, H., D. Fleitmann, R.L. Edwards, X. Wang, F.W. Cruz, A.S. Auler, A. Mangini, Y. Wang, X. Kong, and S.J. Burns. 2009. Timing and structure of the $8.2 \mathrm{kyr} B P$ event inferred from $\delta^{18} \mathrm{O}$ records of stalagmites from China, Oman, and Brazil. Geology 37(11):1007-1010, https://doi.org/10.1130/ G30126A.1.

Clemens, S.C., W. Kuhnt, and L.J. LeVay, and the Expedition 353 Scientists. 2015. Indian monsoon rainfall. International Ocean Discovery Program Expedition 353 Preliminary Report, https://doi.org/ 10.14379/iodp.pr.353.2015.

Deotare, B.C., M.D. Kajale, S.N. Rajaguru, S. Kusumgar, A.J.T. Jull, and J.D. Donahue. 2004. Palaeoenvironmental history of Bap-Malar and Kanod playas of western Rajasthan, Thar desert. Journal of Earth System Science 113(3):403-425, https://doi.org/10.1007/BF02716734.

Dixit, Y., D.A. Hodell, and C.A. Petrie. 2014a. Abrupt weakening of the summer monsoon in northwest India 4100 yr ago. Geology 42(4):339-342, https://doi.org/10.1130/G35236.1.

Dixit, Y., D.A. Hodell, R. Sinha, and C.A. Petrie. 2014b. Abrupt weakening of the Indian summer monsoon at $8.2 \mathrm{kyr}$ BP. Earth and Planetary Science Letters 391:16-23, https://doi.org/10.1016/ j.epsI.2014.01.026.

Dixit, Y., D.A. Hodell, R. Sinha, and C.A. Petrie. 2015. Oxygen isotope analysis of multiple, single ostracod valves as a proxy for combined variability in seasonal temperature and lake water oxygen isotopes. Journal of Paleolimnology 53(1):35-45, https://doi.org/10.1007/s10933-014-9805-3.

Dixit, Y., D.A. Hodell, A. Giesche, S.K. Tandon, F. Gázquez, H.S. Saini, L.C. Skinner, S.A.I. Mujtaba, V. Pawar, R.N. Singh, and C.A. Petrie. 2018. Intensified summer monsoon and the urbanization of Indus Civilization in northwest India. Scientific Reports 8:4225, https://doi.org/10.1038/ s41598-018-22504-5.

Donohoe, A., J. Marshall, D. Ferreira, and D. Mcgee. 2013. The relationship between ITCZ location and cross-equatorial atmospheric heat transport: From the seasonal cycle to the Last Glacial Maximum. Journal of Climate 26(11):3,597-3,618, https://doi.org/10.1175/JCLI-D-12-00467.1.

Enzel, Y., L. Ely, S. Mishra, R. Ramesh, R. Amit, B. Lazar, S. Rajaguru, V. Baker, and A. Sandler. 1999. High-resolution Holocene environmental changes in the Thar Desert, northwestern India. Science 284(5411):125-128, https://doi.org/10.1126/ science.284.5411.125.

Fleitmann, D., S.J. Burns, M. Mudelsee, U. Neff, J. Kramers, A. Mangini, and A. Matter. 2003. Holocene forcing of the Indian Monsoon recorded in a stalagmite from southern Oman. Science 300(5626):1,737-1,739, https://doi.org/ 10.1126/science.1083130.

Gadgil, S., and K.R. Kumar. 2006. The Asian monsoon-Agriculture and economy. Pp. 651-683 in The Asian Monsoon. B. Wang, ed., Springer Praxis Books. Springer, Berlin, Heidelberg, https://doi.org/10.1007/3-540-37722-0_18.

Giesche, A., M. Staubwasser, C.A. Petrie, and D.A. Hodell. 2019. Indian winter and summer monsoon strength over the 4.2 ka BP event in foraminifer isotope records from the Indus River delta in the Arabian Sea. Climate of the Past 15(1):73-90, https://doi.org/10.5194/cp-15-73-2019.

Giosan, L., P.D. Clift, M.G. Macklin, D.Q. Fuller, S. Constantinescu, J.A. Durcan, T. Stevens, G.A.T. Duller, A.R. Tabrez, K. Gangal, and others. 2012. Fluvial landscapes of the Harappan civilization. Proceedings of the National Academy of Sciences of the United States of America 109(26):E1688-E1694, https://doi.org/ 10.1073/pnas.1112743109.

Govil, P., and P.D. Naidu. 2011. Variations of Indian monsoon precipitation during the last $32 \mathrm{kyr}$ reflected in the surface hydrography of the Western Bay of Bengal. Quaternary Science Reviews 30(27-28):3,871-3,879, https://doi.org/ 10.1016/j.quascirev.2011.10.004.

Gupta, A.K., D.M. Anderson, and J.T. Overpeck. 2003. Abrupt changes in the Asian southwest monsoon during the Holocene and their links to the North Atlantic Ocean. Nature 421(6921):354-357, https://doi.org/10.1038/nature01340.

Hodell, D.A., A.V. Turchyn, C.J. Wiseman, J. Escobar, J.H. Curtis, M. Brenner, A. Gilli, A. D. Mueller, F. Anselmetti, and D. Ariztegui. 2012. Late Glacial temperature and precipitation changes in the lowland Neotropics by tandem measurement of $\delta^{18} \mathrm{O}$ in biogenic carbonate and gypsum hydration water. Geochimica et Cosmochimica Acta 77:352-368, https://doi.org/10.1016/j.gca.2011.11.026.

IPCC (Intergovernmental Panel on Climate Change). 2013. Climate Change 2013: The Physical Science Basis. Contribution of Working Group I to the Fifth Assessment Report of the Intergovernmental Panel on Climate Change. T.F. Stocker, D. Qin, G.-K. Plattner, M. Tignor, S.K. Allen, J. Boschung, A. Nauels, Y. Xia, V. Bex, and P.M. Midgley, eds, Cambridge University Press, Cambridge, UK, and New York, NY, USA, 1,535 pp.

IPCC. 2014. Climate Change 2014: Synthesis Report. Contribution of Working Groups I, II and III to the Fifth Assessment Report of the Intergovernmental Panel on Climate Change. R.K. Pachauri and L.A. Meyer, eds, IPCC, Geneva, Switzerland, 151 pp. Ishizaki, Y., K. Yoshimura, S. Kanae, M. Kimoto, N. Kurita, and T. Oki. 2012. Interannual variability of $\mathrm{H}_{2}{ }^{18} \mathrm{O}$ in precipitation over the Asian monsoon region. Journal of Geophysical Research 117(D16), https://doi.org/10.1029/2011JD015890.

Kathayat, G., H. Cheng, A. Sinha, C. Spötl, R.L. Edwards, H. Zhang, X. Li, L. Yi, Y. Ning, Y. Cai, W.L. Lui, and S.F.M. Breitenbach. 2016. Indian monsoon variability on millennial-orbital timescales. Scientific Reports 6(1):24374, https://doi.org/ 10.1038/srep24374.

Kathayat, G., H. Cheng, A. Sinha, L. Yi, X. Li, H. Zhang, H. Li, Y. Ning, and R.L. Edwards. 2017. The Indian monsoon variability and civilization changes in the Indian subcontinent. Science Advances 3(12):e1701296, https://doi.org/10.1126/ sciadv.1701296. 
Kathayat, G., H. Cheng, A. Sinha, M. Berkelhammer, H. Zhang, P. Duan, H. Li, X. Li, Y. Ning, and R.L. Edwards. 2018. Evaluating the timing and struc ture of the 4.2 ka event in the Indian summer monsoon domain from an annually resolved speleothem record from Northeast India. Climate of the Past 14(12):1,869-1,879, https://doi.org/10.5194/ cp-14-1869-2018.

Kim, H.-J., B. Wang, and Q. Ding. 2008. The global monsoon variability simulated by CMIP3 coupled climate models. Journal of Climate 21(20):5,271-5,294, https://doi.org/10.1175/ 2008JCLI2041.1.

Madella, M., and D.Q. Fuller. 2006. Palaeoecology and the Harappan Civilisation of South Asia: A reconsideration. Quaternary Science Reviews 25(11):1,283-1,301, https://doi.org/10.1016/ j.quascirev.2005.10.012.

Menzel, P., B. Gaye, M.G. Wiesner, S. Prasad, M. Stebich, B.K. Das, A. Anoop, N. Riedel, and N. Basavaiah. 2013. Influence of bottom water anoxia on nitrogen isotopic ratios and amino acid contributions of recent sediments from small eutrophic Lonar Lake, central India. Limnology and Oceanography 58(3):1,061-1,074, https://doi.org/ 10.4319/lo.2013.58.3.1061.

Mishra, A.K., and V. Nagaraju. 2019. Space-based monitoring of severe flooding of a southern state in India during south-west monsoon season of 2018 Natural Hazards 97(2):949-953, https://doi.org/ 10.1007/s11069-019-03673-6.

Nakamura, A., Y. Yokoyama, H. Maemoku, H. Yagi, M. Okamura, H. Matsuoka, N. Miyake, T. Osada, D.P. Adhikari, V. Dangol, and others. 2016. Weak monsoon event at 4.2 ka recorded in sediment from Lake Rara, Himalayas. Japanese Quaternary Studies 397:349-359, https://doi.org/10.1016/ j.quaint.2015.05.053.

Pal, I., and A. Al-Tabbaa. 2009. Trends in seasonal precipitation extremes: An indicator of 'climate change' in Kerala, India. Journal of Hydrology 367(1-2):62-69, https://doi.org/10.1016/ j.jhydrol.2008.12.025.

Petrie, C.A., and J. Bates. 2017. 'Multi-cropping', intercropping and adaptation to variable environments in Indus South Asia. Journal of World Prehistory 30(2):81-130, https://doi.org/10.1007/ s10963-017-9101-z.

Petrie, C.A., R.N. Singh, J. Bates, Y. Dixit, C.A.I. French, D.A. Hodell, P.J. Jones, C. Lancelotti, F. Lynam, S. Neogi, and others. 2017. Adaptation to variable environments, resilience to climate change: Investigating land, water and settlement in Indus Northwest India. Current Anthropology 58(1), https://doi.org/10.1086/690112.

Phadtare, N.R. 2000. Sharp decrease in summer monsoon strength 4000-3500 cal yr BP in the central higher Himalaya of India based on pollen evidence from alpine peat. Quaternary Research 53(1):122-129, https://doi.org/10.1006/ qres.1999.2108.

Pokharia, A.K., R. Agnihotri, S. Sharma, S. Bajpai, J. Nath, R.N. Kumaran, and B.C. Negi. 2017. Altered cropping pattern and cultural continuation with declined prosperity following abrupt and extreme arid event at $\sim 4,200$ yrs BP: Evidence from an Indus archaeological site Khirsara, Gujarat, western India. PloS One 12(10):e0185684, https://doi.org/ 10.1371/journal.pone.0185684.

Ponton, C., L. Giosan, T.I. Eglinton, D.Q. Fuller, J.E. Johnson, P. Kumar, and T.S. Collett. 2012. Holocene aridification of India. Geophysical Research Letters 39(3), https://doi.org/10.1029/ 2011 GL050722.

Possehl, G.L. 2003. The Indus Civilization: An introduction to environment, subsistence, and cultural history. Pp. 1-20 in Indus Ethnobiology: New Perspectives from the Field. S.A. Weber and W.R. Belcher, eds, Lexington Books, Lanham, MD.
Prasad, S., and Y. Enzel. 2006. Holocene paleoclimates of India. Quaternary Research 66(3):442-453, https://doi.org/ 10.1016/j.yqres.2006.05.008

Prasad, S., A. Anoop, N. Riedel, S. Sarkar, P. Menzel, N. Basavaiah, R. Krishnan, D. Fuller, B. Plessen, B. Gaye, and others. 2014. Prolonged monsoon droughts and links to Indo-Pacific warm pool: A Holocene record from Lonar Lake, central India. Earth and Planetary Science Letters 391:171-182, https://doi.org/https://doi.org/10.1016/j.epsl. 2014.01.043.

Rashid, H., E. England, L. Thompson, and L. Polyak. 2011. Late glacial to Holocene Indian summer monsoon variability based upon sediment records taken from the Bay of Bengal. Terrestrial, Atmospheric and Oceanic Science 22:215-228, https://doi.org/10.3319/TAO.2010.09.17.02(TibXS).

Saini, H.S., S.K. Tandon, S.A.I. Mujtaba, and N.C. Pant 2005. Lake deposits of the northeastern margin of Thar Desert: Holocene(?) Palaeoclimatic implications. Current Science 88(12):1,994-2,000.

Seneviratne, S.I., and M. Hauser. 2020. Regional climate sensitivity of climate extremes in CMIP6 vs CMIP5 multi-model ensembles. Earth's Future e2019EF001474, https://doi.org/ 10.1029/2019EF001474.

Sengupta, S., and A. Sarkar. 2006. Stable isotope evidence of dual (Arabian Sea and Bay of Bengal) vapour sources in monsoonal precipitation over north India. Earth and Planetary Science Letters 250(3-4):511-521, https://doi.org/10.1016/ j.epsl.2006.08.011.

Singh, G., R.D. Joshi, and A.B. Singh. 1972. Stratigraphic and radiocarbon evidence for the age and development of three salt lake deposits in Rajasthan, India. Quaternary Research 2(4):496-505, https://doi.org/ 10.1016/0033-5894(72)90088-9.

Singh, G., R. Wasson, and D. Agrawal. 1990. Vegetational and seasonal climatic changes since the last full glacial in the Thar Desert, northwestern India. Review of Palaeobotany and Palynology 64(1-4):351-358, https://doi.org/ 10.1016/0034-6667(90)90151-8.

Sinha, R. 2008. Kosi: Rising waters, dynamic channels and human disasters. Economic \& Political Weekly 43(46).

Sinha, R., W. Smykatz-Kloss, D. Stüben, S.P. Harrison, Z. Berner, and U. Kramar. 2006. Late Quaternary palaeoclimatic reconstruction from the lacustrine sediments of the Sambhar playa core, Thar Desert margin, India. Palaeogeography, Palaeoclimatology, Palaeoecology 233(3):252-270, https://doi.org/ 10.1016/j.palaeo.2005.09.012.

Staubwasser, M., F. Sirocko, P.M. Grootes, and M. Segl. 2003. Climate change at the $4.2 \mathrm{ka}$ $\mathrm{BP}$ termination of the Indus valley civilization and Holocene south Asian monsoon variability. Geophysical Research Letters 30(8), https://doi.org/ 10.1029/2002GL016822.

Toth, L.T., R.B. Aronson, S.V. Vollmer, J.W. Hobbs, D.H. Urrego, H. Cheng, I.C. Enochs, D.J. Combosch, R. van Woesik, and I.G. Macintyre. 2012. ENSO drove 2500-year collapse of eastern Pacific coral reefs. Science 337(6090):81-84, https://doi.org/ 10.1126/science.1221168.

Walker, M., M.J. Head, J. Lowe, M. Berkelhammer, S. Björck, H. Cheng, L.C. Cwynar, D. Fisher, V. Gkinis, A. Long, and others. 2019. Subdividing the Holocene series/epoch: Formalization of stages/ages and subseries/subepochs, and designation of GSSPs and auxiliary stratotypes. Journal of Quaternary Science 34(3):173-186, https://doi.org/10.1002/jqs.3097.
Wang, B., and Q. Ding. 2008. Global monsoon:

Dominant mode of annual variation in the tropics. Dynamics of Atmospheres and Oceans 44(3-4):165-183, https://doi.org/10.1016/ j.dynatmoce.2007.05.002.

Wang, C. 2019. Three-ocean interactions and climate variability: A review and perspective. Climate Dynamics 53(7):5,119-5,136, https://doi.org/10.1007/ s00382-019-04930-x.

Wang, P.X., B. Wang, H. Cheng, J. Fasullo, Z. Guo, T. Kiefer, and Z. Liu. 2017. The global monsoon across time scales: Mechanisms and outstanding issues. Earth-Science Reviews 174:84-121, https://doi.org/10.1016/j.earscirev.2017.07.006.

Wang, Y.J., H. Cheng, R.L. Edwards, Z.S. An, J.Y. Wu, C.-C. Shen, and J.A. Dorale. 2001. A high-resolution absolute-dated Late Pleistocene monsoon record from Hulu Cave, China. Science 294(5550):2345, https://doi.org/10.1126/science.1064618.

Wang, Y.J., H. Cheng, R.L. Edwards, Y. He, X. Kong, Z. An, J. Wu, M.J. Kelly, C.A. Dykoski, and X. Li. 2005. The Holocene Asian monsoon: Links to solar changes and North Atlantic climate. Science 308(5723):854-857, https://doi.org/10.1126/ science.1106296.

Wasson, R.J., G.I. Smith, and D.P. Agrawal. 1984. Late quaternary sediments, minerals, and inferred geochemical history of Didwana Lake, Thar Desert, India. Palaeogeography, Palaeoclimatology, Palaeoecology 46(4):345-372, https://doi.org/ 10.1016/0031-0182(84)90006-3.

Weber, S.A. 2003. Archaeobotany at Harappa: Indications for change. Pp. 175-198 in Indus Ethnobiology: New Perspectives from the Field S.A. Weber and W.R. Belcher, eds, Lexington Books, Lanham MD.

Weiss, H. 2016. Global megadrought, societal collapse and resilience at 4.2-3.9 ka BP across the Mediterranean and West Asia. PAGES Magazine 24(2):62-63.

Wright, R.P. 2010. The Ancient Indus: Urbanism, Economy, and Society. Cambridge University Press, Cambridge, $418 \mathrm{pp}$.

\section{ACKNOWLEDGMENTS}

Special issue guest editor Amelia Shevenell and two anonymous reviewers of this article are thanked for constructive reviews. David Hodell, Cameron Petrie, Ayan Bhowmik, and Adam Switzer are acknowledged for insightful discussions at various points in time.

\section{AUTHOR}

Yama Dixit (ydixit@ntu.edu.sg) is Research Fellow, Earth Observatory of Singapore, Nanyang Technological University, Singapore.

\section{ARTICLE CITATION}

Dixit, Y. 2020. Regional character of the "global monsoon": Paleoclimate insights from northwest Indian lacustrine sediments. Oceanography 33(2):56-64, https://doi.org/10.5670/oceanog.2020.206.

\section{COPYRIGHT \& USAGE}

This is an open access article made available under the terms of the Creative Commons Attribution 4.0 International License (https://creativecommons.org/ licenses/by/4.0/), which permits use, sharing, adaptation, distribution, and reproduction in any medium or format as long as users cite the materials appropriately, provide a link to the Creative Commons license, and indicate the changes that were made to the original content. 